\title{
RETENÇÃO DE METAIS PESADOS EM MICÉLIO DE FUNGOS MICORRÍZICOS ARBUSCULARES
}

Lucélia Cabral

Departamento de Ciência do Solo, Universidade Federal do Rio Grande do Sul, Av. Bento Gonçalves, 7712, $91540-000$ Porto Alegre - RS, Brasil José Oswaldo Siqueira e Claúdio Roberto Fonsêca Sousa Soares*

Departamento de Ciência do Solo, Universidade Federal de Lavras, CP 3037, 37200-000 Lavras - MG, Brasil

José Eduardo Brasil Pereira Pinto

Departamento de Agricultura, Universidade Federal de Lavras, CP 3037, 37200-000 Lavras - MG, Brasil

No vol. 33, n. 1, 25-29, na p. 27, por um equívoco da editoria, a Figura 1 foi repetida como Figura 2. Segue abaixo a Figura 2 correta.

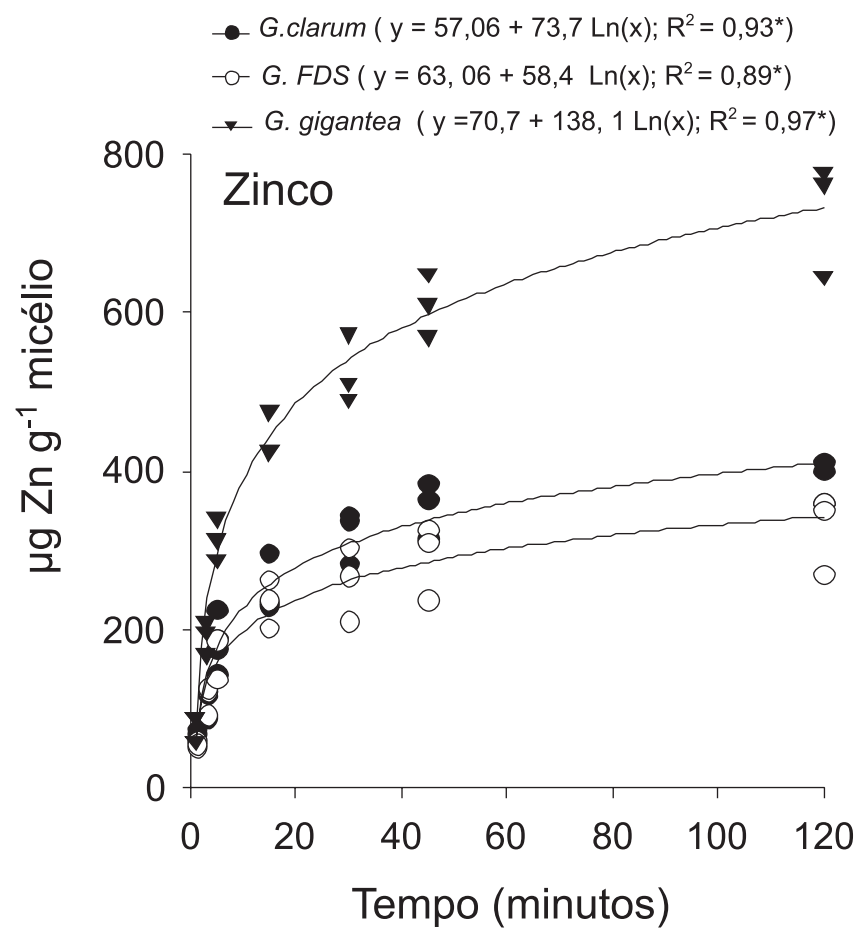

Figura 2. Taxa de retenção de Zn em micélio de Glomus clarum, Glomus FDSl e Gigaspora gigantea in vitro ( $\mu g g^{-1}$ micélio fúngico) 